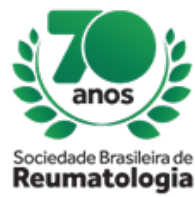

\title{
DIFFUSE LARGE-B-CELL LYMPHOMA IN A PATIENT WITH SJOGREN SYNDROME AND
} CRYOGLOBULINEMIC VASCULITIS: A CASE REPORT.

\author{
CAMILA DA SILVA CENDON DURAN (USP-SP, São Paulo, SP, Brasil), CARLA BALEEIRO RODRIGUES SILVA \\ (USP-SP, São Paulo, SP, Brasil), LUCAS BRANDÃO ARAUJO DA SILVA (USP-SP, São Paulo, SP, Brasil), \\ CARLO SCOGNAMIGLIO RENNER ARAUJO (USP-SP, São Paulo, SP, Brasil), LISSIANE KARINE NORONHA \\ GUEDES (USP-SP, São Paulo, SP, Brasil), LUCIANA PARENTE COSTA SEGURO (USP-SP, São Paulo, SP, \\ Brasil), ROSA MARIA RODRIGUES PEREIRA (USP-SP, São Paulo, SP, Brasil), EDUARDO FERREIRA BORBA \\ NETO (USP-SP, São Paulo, SP, Brasil)
}

\section{BACKGROUND}

Sjogren's syndrome (SS) is a chronic autoimmune disease characterized by lymphocytic infiltration, especially of exocrine salivary and lacrimal glands, which leads to gradual destruction and consequently xerophthalmia and xerostomia. Symptomatic cryoglobulinemic vasculitis can occurs in 3-4\% of SS and nonHodgkin Lymphoma represents the major complication of the disease with incidence 20-times greater in SS than in the general population.

\section{CASE REPORT}

Female, 54 years-old, diagnosed with Sjogren's Syndrome 2 years ago. At the diagnosis referred xerostomia, xerophthalmia and palpable purpura in lower limbs which the biopsy showed leukocytoclastic vasculitis. Currently presenting with unintentional weight loss (approximately 10kg), epigastric pain, nausea and vomiting. The patient completed treatment for gastric ulcers and $\mathrm{H}$. pylori infection without improvement. She was also presenting purpura and paresthesia in lower limbs and reported a unilateral episode of parotiditis four months ago with spontaneous improvement. Prednisone $1 \mathrm{mg} / \mathrm{kg} /$ day was prescribed and a request for hospitalization was made. Performed exams showed: ANA 1/320 nuclear fine speckled pattern, Anti-Ro 158.7U/mL (Reagent> 25), Rheumatoid Factor $181.7 \mathrm{UI} / \mathrm{mL}$ (Non-reagent <14). Low levels of C3: $49 \mathrm{mg} / \mathrm{dL}$ (RV: $67-149$ ) and C4: $<2 \mathrm{mg} / \mathrm{dL}$ (RV: 10-38). Renal function, venous blood gas and serum protein electrophoresis were within the normal ranges. Urine I showed proteinuria, leukocyturia and 17 erythrocytes/field. Urinary protein/creatinine: $0.680 \mathrm{~g} / \mathrm{g}$. Dosage of cryoglobulins $1651 \mathrm{UG} / \mathrm{ml}$ (VR: 80UG/ml). Electroneuromyography evidenced sensory axonal polyneuropathy in lower limbs. In view of the evidence of cryoglobulinemic vasculitis with renal and neurological concomitants, pulse therapy with Methylprednisolone $1 \mathrm{~g}$ for 3 days was performed and Rituximab was indicated. Endoscopy was made and evidenced an infiltrative lesion extending from the esophagogastric transition to middle antrum. Histopathology and immunohistochemistry revealed diffuse large B-cell lymphoma. Patient will start chemotherapy which includes the use of Rituximab.

\section{CONCLUSION}

Cryoglobulinemia in patients with Sjogren's syndrome usually occurs in association with leukocytoclastic vasculitis and hypocomplementenemia. Affected patients are at increased risk of B-cell lymphoma and fatal vasculitis. Non-Hodgkin's lymphoma represents the major complication of the disease with prevalence of 5-7\% among these patients. Mucosal-Associated Lymphoid Tissue Lymphomas (MALT) is the most common subtype, followed by diffuse large B-cell lymphoma. The authors emphasize that in the follow-up of patients with Sjögren's Syndrome, attention should be paid to factors that may suggest the onset of this complication, such as episodes of persistent parotiditis, fall in complement levels, cutaneous vasculitis, cryoglobulinemia and persistent lymphadenopathy. 